\title{
The actin cytoskeleton and small $G$ protein RhoA are not involved in flow-dependent activation of $\mathrm{ENaC}$
}

\author{
Alexey V Karpushev ${ }^{1}$, Daria V Ilatovskaya ${ }^{1,3}$, Alexander Staruschenko ${ }^{1,2^{*}}$
}

\begin{abstract}
Background: Epithelial cells are exposed to a variety of mechanical stimuli. Epithelial $\mathrm{Na}^{+}$channels (ENaC) mediate sodium transport across apical membranes of epithelial cells that line the distal nephron, airway and alveoli, and distal colon. Early investigations into stretch sensitivity of $\mathrm{ENaC}$ were controversial. However, recent studies are supportive of ENaC's mechanosensitivity. This work studied whether flow-dependent activation of ENaC is modulated by changes in the state of the actin cytoskeleton and whether small GTPase RhoA is involved in flowmediated increase of ENaC activity.

Findings: Pretreatment with Cytochalasin D and Latrunculin B for 20 min and 1-2 hrs to disassemble F-actin had no effect on flow-mediated increase of amiloride-sensitive current. Overexpression of $\mathrm{ENaC}$ with constitutively active (G14V) or dominant negative (T19N) RhoA similarly had no effect on flow-dependent activation of ENaC activity. In addition, we did not observe changes when we inhibited Rho-kinase with Y27632.

Conclusions: Our results suggest that the flow-dependent activation of ENaC is not influenced by small GTPase RhoA and modifications in the actin cytoskeleton.
\end{abstract}

\section{Introduction}

The long term control of blood pressure involves $\mathrm{Na}^{+}$ homeostasis through the precise regulation of the Epithelial $\mathrm{Na}^{+}$Channel $(\mathrm{ENaC})$ in the aldosterone-sensitive distal nephron [1,2]. The rate of $\mathrm{Na}^{+}$absorption varies widely in response to conditions of $\mathrm{Na}^{+}$deprivation and $\mathrm{Na}^{+}$excess. The physiological relevance of the mechanosensitivity of $\mathrm{ENaC}$ becomes clearly apparent in the mammalian cortical collecting ducts (CCDs), a nephron segment subject to continuous variations in rates of tubular flow. Flow rates within the distal nephron, including CCDs, increase in response to expansion of the extracellular fluid volume or administration of diuretics and fall in response to volume depletion [3]. Palmer and Frindt studied whether mechanical perturbations could influence $\mathrm{ENaC}$ kinetics or gating mode in freshly isolated rat CCDs. In most cases negative pressure applied to the patch clamp pipette had no effect on channel behaviour. However they also observed

\footnotetext{
* Correspondence: staruschenko@mcw.edu

'Department of Physiology, Medical College of Wisconsin, 8701 Watertown Plank Rd., Milwaukee, WI 53226, USA
}

a rapid and reversible increase in channel open probability $\left(P_{\mathrm{o}}\right)$ in 6 out of 22 patches [4]. In one experiment, there was a reversible decrease. They proposed that the variability in the response could reflect differences in the mechanical deformations of the apical membrane within the tip of the pipette [4]. Later Awayda and Subramanyam proposed that $\mathrm{rENaC}$ is not directly mechanosensitive when overexpressed in oocytes [5]. However, recent data are mostly supportive of $\mathrm{ENaC}$ 's mechanosensitivity. Thus it was shown that the response to flow reflects a rapid increase in the open probability of ENaC [6-11]. Moreover, it was proposed that aldosterone modifies the osmotic stressinduced regulation of $\mathrm{ENaC}$ trafficking [10].

While there are many studies demonstrating flowmediated regulation of $\mathrm{ENaC}$, mechanisms underlying this activation of $\mathrm{ENaC}$ are not clear yet. Biological membranes are capable of deforming in response to external stresses or through association with the cytoskeleton. Cytoskeletal elements are evidently an important part of ion transport regulation in epithelia. Mechanosensitive channels in various eukaryotic cells

\section{() Biomed Central}

(c) 2010 Staruschenko et al; licensee BioMed Central Ltd. This is an open access article distributed under the terms of the Creative Commons Attribution License (http://creativecommons.org/licenses/by/2.0), which permits unrestricted use, distribution, and reproduction in any medium, provided the original work is properly cited. 
are thought to be functionally and structurally coupled to the cortical cytoskeleton. For instance, we have shown previously that the F-actin disassembly resulted in a reduction of the amplitude of stretch-activated currents in human leukaemia K562 cells [12]. Achard et al. [13] demonstrated in human B lymphocytes that a modest increase in the hydrostatic pressure of the solution bathing the cells activated amiloride-sensitive sodium channels, a response requiring an intact cytoskeleton. Inhibition of microtubule polymerization with colchicine prevented stretch-induced activation of $\mathrm{Na}^{+}$channels [13]. Moreover, it was recently shown that mechanical stimulation of actin stress fibers can activate mechanosensitive channels in HUVEC cells [14].

Actin cytoskeleton and microtubules play an important role in the regulation of membrane transport processes in epithelia [15-19]. We found recently that the cytoskeleton is necessary for small $\mathrm{G}$ protein mediated increase of $\mathrm{ENaC}$ activity [20]. Acute destroying of the actin cytoskeleton with Cytochalasin D increases $\mathrm{ENaC}$ open probability similar to flow-dependent effect on $\mathrm{ENaC}$ activity. Small G proteins, molecular switches that control the activity of cellular and membrane proteins, regulate a wide variety of cell functions. As we have shown previously, RhoA activates $\mathrm{ENaC}$ via Rho-kinase and subsequent activation of $\mathrm{PI}(4) \mathrm{P}$ 5-kinase with concomitant increases in $\mathrm{PI}(4,5) \mathrm{P}_{2}$ levels and promotes channel insertion into the plasma membrane [21-23].

The present study was designed to investigate a hypothesis that the mechanical activation mediated by the cytoskeleton is of considerable physiological relevance and that this $\mathrm{ENaC}$ feature could therefore represent a novel nonhormonal regulatory mechanism responsible for flow-mediated activation of $\mathrm{ENaC}$. Moreover, we feel that small G proteins may play a key role in mechanosensitive activation of the $\mathrm{ENaC}$ channel and flow-dependent regulation of $\mathrm{Na}^{+}$transport in the distal nephron. Experiments in this study examined these hypotheses. However, we find that the actin cytoskeleton and small $G$ protein RhoA are not required for flowmediated activation of $\mathrm{ENaC}$.

\section{Results}

To investigate flow-dependent activation of $\mathrm{ENaC}$ activity, we reconstituted the channel in Chinese hamster ovary $(\mathrm{CHO})$ cells. $\mathrm{mENaC}$ was reconstituted by coexpressing $\alpha-, \beta$ - and $\gamma$-channel subunits. Flowdependent activation of $\mathrm{ENaC}$ activity was induced by activation of bath perfusion surrounding the cells. Amiloride-sensitive current was normalized to the basal activity in the absence of perfusion. Figure 1 shows an experimental setup and protocols used to measure amiloride sensitive whole cell currents in $\mathrm{CHO}$ cells. Different experimental systems have their own limitations. Initially we tested the effects of flow stimulation on the whole-cell currents when $\mathrm{ENaC}$ was expressed in $\mathrm{CHO}$ cells. As shown in Figure 2 flow significantly increases amiloride sensitive current in $\mathrm{CHO}$ cells over-expressed with all three $\mathrm{ENaC}$ subunits. Figure $2 \mathrm{~A}$ presents the macroscopic currents from representative whole cell experiments elicited by a set of test pulses stepping from a holding potential of $40 \mathrm{mV}$ to $60 \mathrm{mV}$ to $-100 \mathrm{mV}$ (see protocol in Figure 1B). As reported previously, $\mathrm{CHO}$ cells contain no endogenous, amiloride-sensitive ENaC current [24]. Currents before (left) and after (middle - low perfusion, and right - high perfusion) flow stimulation are shown. High and low perfusion rates were obtained by increasing the amount of solution that flows through the bath chamber. The high perfusion was the rate threshold beyond that no further increase in whole cell current was observed. In our experiments the effect of flow on the whole cell currents was only slightly progressive (Figure 2A). Similarly, stretch-activation of amiloride-sensitive $\mathrm{Na}^{+}$ channels in human B lymphocytes occurred once a threshold value of hydrostatic pressure was reached. On reaching the threshold, the currents increased maximally, and there was no further increase in current amplitude by further elevation of hydrostatic pressure [13]. Awayda and Subramanyam have shown previously that $\mathrm{ENaC}$ whole-cell currents were insensitive to osmotic cell swelling when $\mathrm{rENaC}$ was over-expressed in oocytes [5]. They also observed that amiloride-insensitive currents were mediated by cell swelling. Thus, we have tested an effect of flow when cells were pretreated with amiloride. However flow had no effect when amiloride was included in the bath solution (Figure 2B). The finding that the flow-activated current was sensitive to amiloride and that there was no flow-mediated current in untransfected cells (data not shown) clearly indicates that $\mathrm{ENaC}$ is activated by flow and that flow activation is not a secondary effect of the experimental setup. Figure $2 \mathrm{C}$ shows current through $\mathrm{ENaC}$ in the presence and absence of perfusion elicited by a train of voltage ramps applied every $3 \mathrm{~s}$ over the course of several minutes. As the perfusion was stopped to maintain a constant bath level, ENaC activity decreased over time indicating that flow-stimulation was necessary to enhance channel activity. Flow-induced activation of $\mathrm{ENaC}$ was fast and completely reversible as shown in Figure $2 \mathrm{C}$. The effect of flow on the current was sustained as long as perfusion remained elevated and was immediately reversed (Figure 2C). Figure 2D shows the current-voltage (I-V) relations for macroscopic ENaC current in the control conditions and after flow-dependent activation. As summarized in Figure 2E, perfusion significantly increased $\mathrm{ENaC}$ activity from $1.88 \pm 0.37$ to $3.45 \pm 0.59 \mathrm{nA}(\mathrm{n}=18)$. 


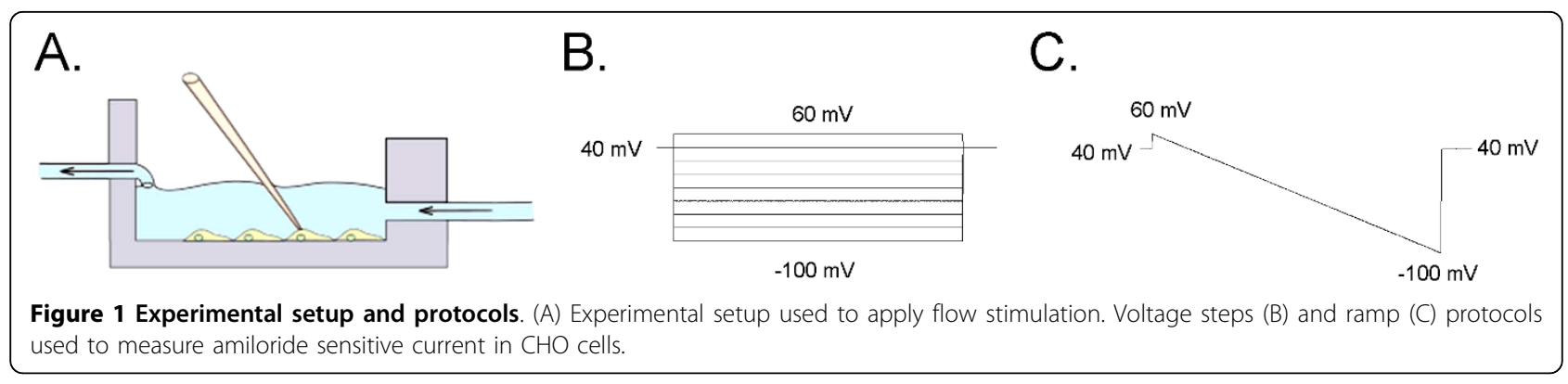

To estimate whether the flow-dependent activation of $\mathrm{ENaC}$ activity is mediated by the actin cytoskeleton, we pretreated $\mathrm{CHO}$ cell with Cytochalasin $\mathrm{D}(\mathrm{CyD})$ and Latrunculin B (LatB), well known unrelated inhibitors of actin polymerization. CytD binds to the barbed, fast growing plus ends of microfilaments, which then blocks both the assembly and disassembly of individual actin monomers from the bound end $[12,25]$. In contrast, LatB binds actin monomers and prevents them from polymerizing [26]. We and others have shown earlier that acute application of CytD induced rapid increase in $\mathrm{ENaC}$ activity via affecting channel open probability $(P o)$. In contrast, long pretreatment with CytD significantly decreased ENaC activity $[15,20]$. Surprisingly,
LatB has no effect on $\mathrm{ENaC}$ activity (data not shown). We suggest that as these two reagents have a completely different mechanism leading to disassembly of action cytoskeleton it is more likely that namely actin assembly modulation is responsible for cytoskeleton-dependent mechanism of $\mathrm{ENaC}$ regulation. However this exciting finding needs further investigation.

For experiments with inhibitors of the actin cytoskeleton, $\mathrm{CHO}$ cells were initially flow-stimulated and $\mathrm{ENaC}$ activity was measured before and after the perfusion was eliminated. However, neither 20 min nor 1-2 hrs treatment with CytD or LatB changed the extent of inhibition of flow-stimulated amiloride-sensitive current (Figure 3A). Furthermore, we tested whether destroying

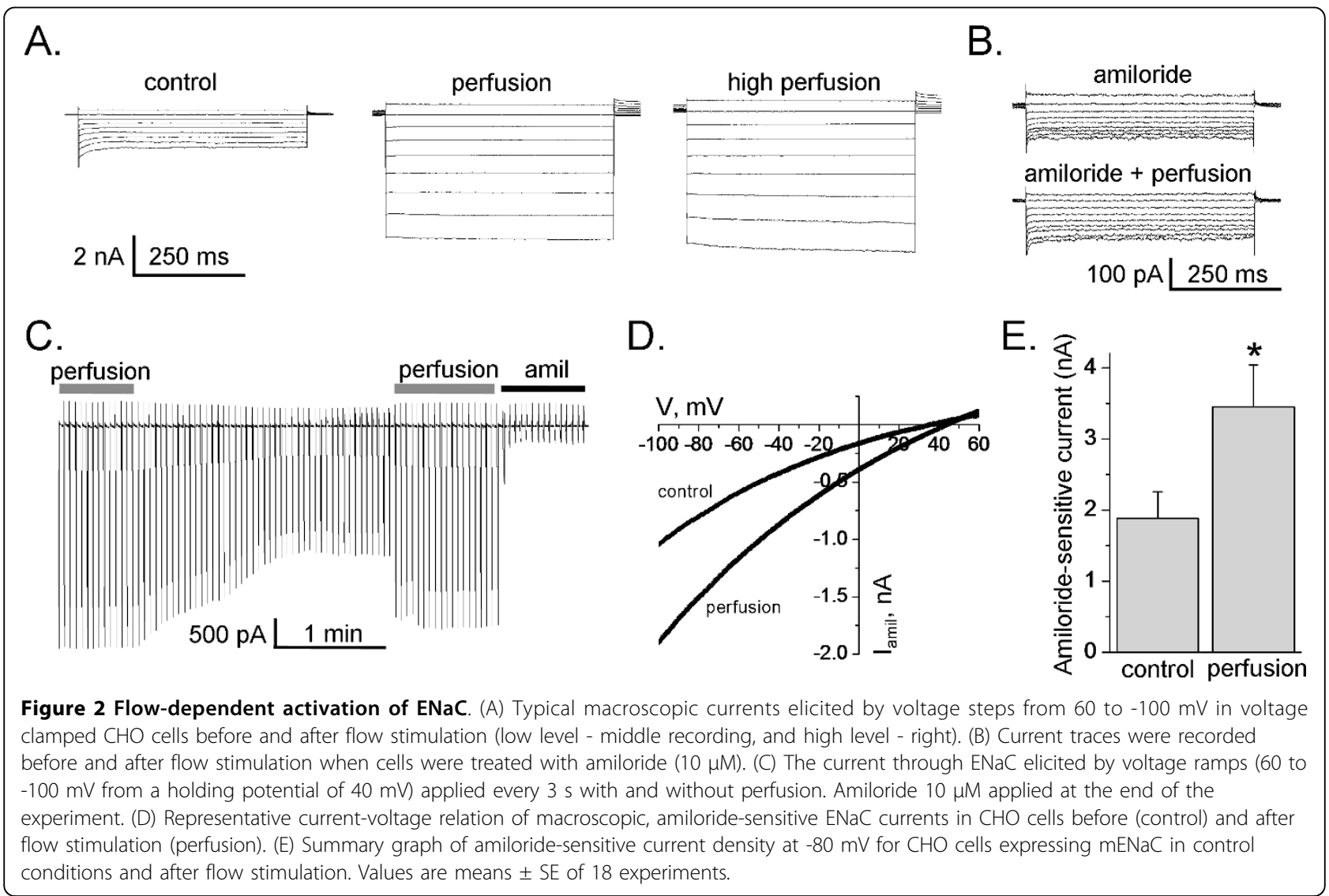



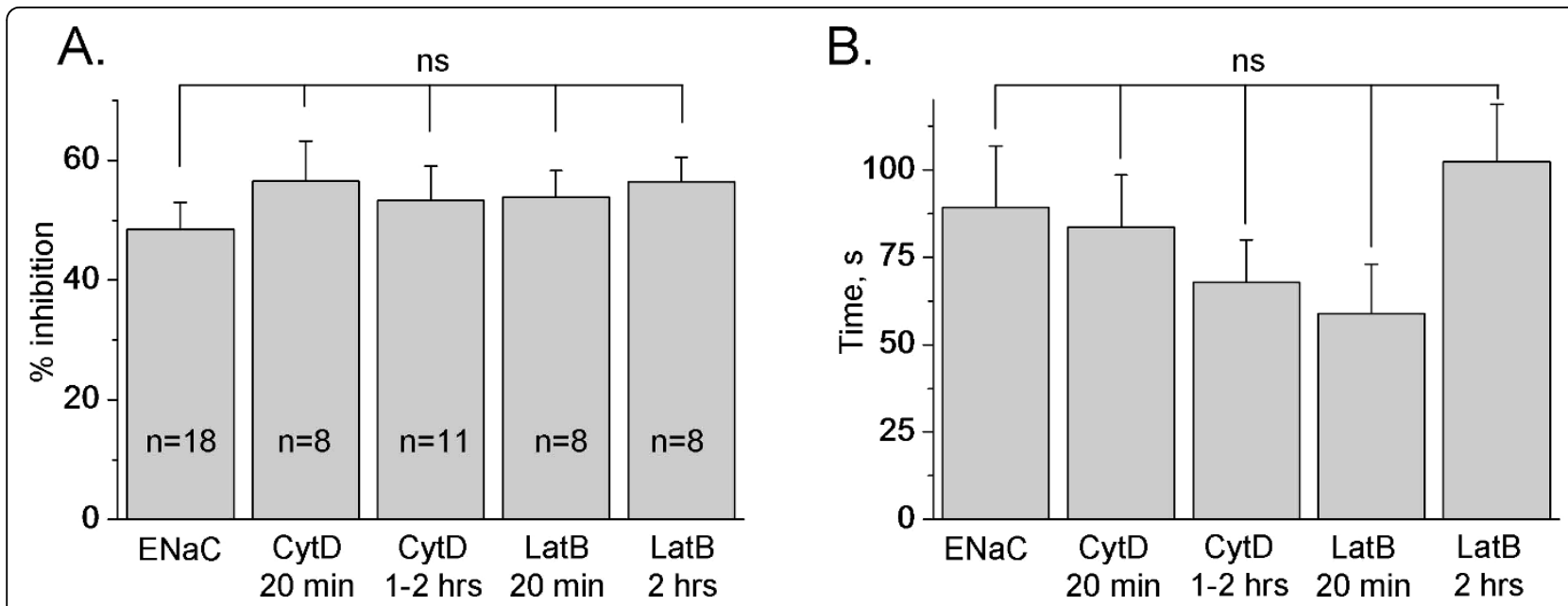

Figure 3 Destroying of the actin cytoskeleton does not affect flow-mediated activation of ENaC. (A) Summary graph of inhibition extent of amiloride-sensitive current. The peak response of the whole-cell amiloride-sensitive current at basal conditions was normalized to the flowstimulated currents. All three $\mathrm{mENaC}$ subunits were overexpressed in $\mathrm{CHO}$ cells and $\mathrm{ENaC}$ activity recorded either with or without perfusion. CHO cells were not treated or pretreated with Cytochalasin D $(C y t D, 10 \mu \mathrm{g} / \mathrm{ml})$ or Latrunculin B $(\mathrm{LatB}, 5 \mu \mathrm{M})$ for 20 min and 1-2 hrs, respectively. The number of observations for each group is shown. (B) Summary graph of the time constants describing the rate of ENaC inhibition following switching off flow stimulation of ENaC activity in $\mathrm{CHO}$ cells not treated and pretreated with CytD or LatB as presented in (A).

of the actin cytoskeleton has an effect on the rate of $\mathrm{ENaC}$ inhibition. Time constants are calculated as the time period needed for the current to decrease by $50 \%$ after the flow is switched off compared to the current when flow is activated. The time constants describing $\mathrm{ENaC}$ inhibition also did not change when the actin cytoskeleton was destroyed (Figure 3B).

To demonstrate that treatment with CytD and LatB modulated the actin cytoskeleton we performed fluorescence staining of $\mathrm{CHO}$ cells with rhodamine-phalloidin. $\mathrm{CHO}$ cells were incubated with CytD $(20 \mu \mathrm{M} ; 2 \mathrm{hrs})$ and with LatB ( $5 \mu \mathrm{M} ; 2 \mathrm{hrs})$ and then stained to visualize changes of the actin cytoskeleton state of a cell. Fluorescence microscopy showed that treatment of $\mathrm{CHO}$ cells with CytD and LatB caused disruption of the actin cytoskeleton. Untreated cells exhibit typical cortical and filamentous actin staining that becomes depolymerized with the addition of $20 \mu \mathrm{M}$ CytD or $5 \mu \mathrm{M}$ LatB (Figure 4).

To investigate the involvement of small $G$ protein RhoA in the flow-dependent increase of $\mathrm{ENaC}$ activity, we co-expressed $\mathrm{ENaC}$ subunits with constitutively active (G14V) and dominant negative (T19N) RhoA. As we have shown previously, wild type and mutant RhoA were over-expressed in $\mathrm{CHO}$ cells and modulated $\mathrm{ENaC}$ activity [21-23]. In addition, we pretreated $\mathrm{CHO}$ cells either expressing $\mathrm{ENaC}$ alone or co-expressed with RhoA $^{\text {G14V }}$ with Rho-kinase inhibitor (Y27632; $1 \mu \mathrm{M} ; 1$ hr). Rho-kinase is a downstream effector of RhoA with respect to $\mathrm{ENaC}$ [23]. However the extent of inhibition of flow-mediated amiloride-sensitive current was similar in all studied groups (Figure 5A). Also, the time constants describing ENaC inhibition did not change (Figure $5 \mathrm{~B})$. We conclude that the actin cytoskeleton and small $\mathrm{G}$ protein RhoA are not involved in flow-dependent activation of $\mathrm{ENaC}$.

\section{Discussion}

The epithelial $\mathrm{Na}^{+}$channel is an essential channel responsible for $\mathrm{Na}^{+}$reabsorption. Laminar shear stress induced by fluid flow activates $\mathrm{ENaC}$ activity in vivo and in vitro. Different studies indicate that $\mathrm{ENaC}$ responds to mechanical forces such as laminar shear stress, osmotic stress and hydrostatic pressure [4-9,13,27-31]. Thus, current investigations established that $\mathrm{ENaC}$ is most likely a mechanosensitive ion channel $[27,30,32,33]$. Shear force-induced ENaC activation is mediated by an increase in $P o[7,8,34]$ and is not affected by changes in $\left[\mathrm{Ca}^{2+}\right]$ or membrane trafficking [31]. Moreover, it was shown that the flow-dependent activation of $\mathrm{ENaC}$ is not influenced by modifications in the intrinsic properties of the plasma membrane. Flow-dependent activation of $\mathrm{ENaC}$ is not affected by the modifications induced by temperature and the content of membrane cholesterol [9]. Trypsin, a protease affecting $\mathrm{ENaC} \mathrm{Po}$, also did not change ratios of the shear stress-induced effects $[8,31]$. Fronius and Clauss proposed that large extracellular loops of $\mathrm{ENaC}$ play a major role in this mechanical activation [30]. According to this topology, extracellular loops of the channel can be described as mechanosensors oriented into lumen of the CCD. It has been supposed that cystein rich domains of the extracellular 

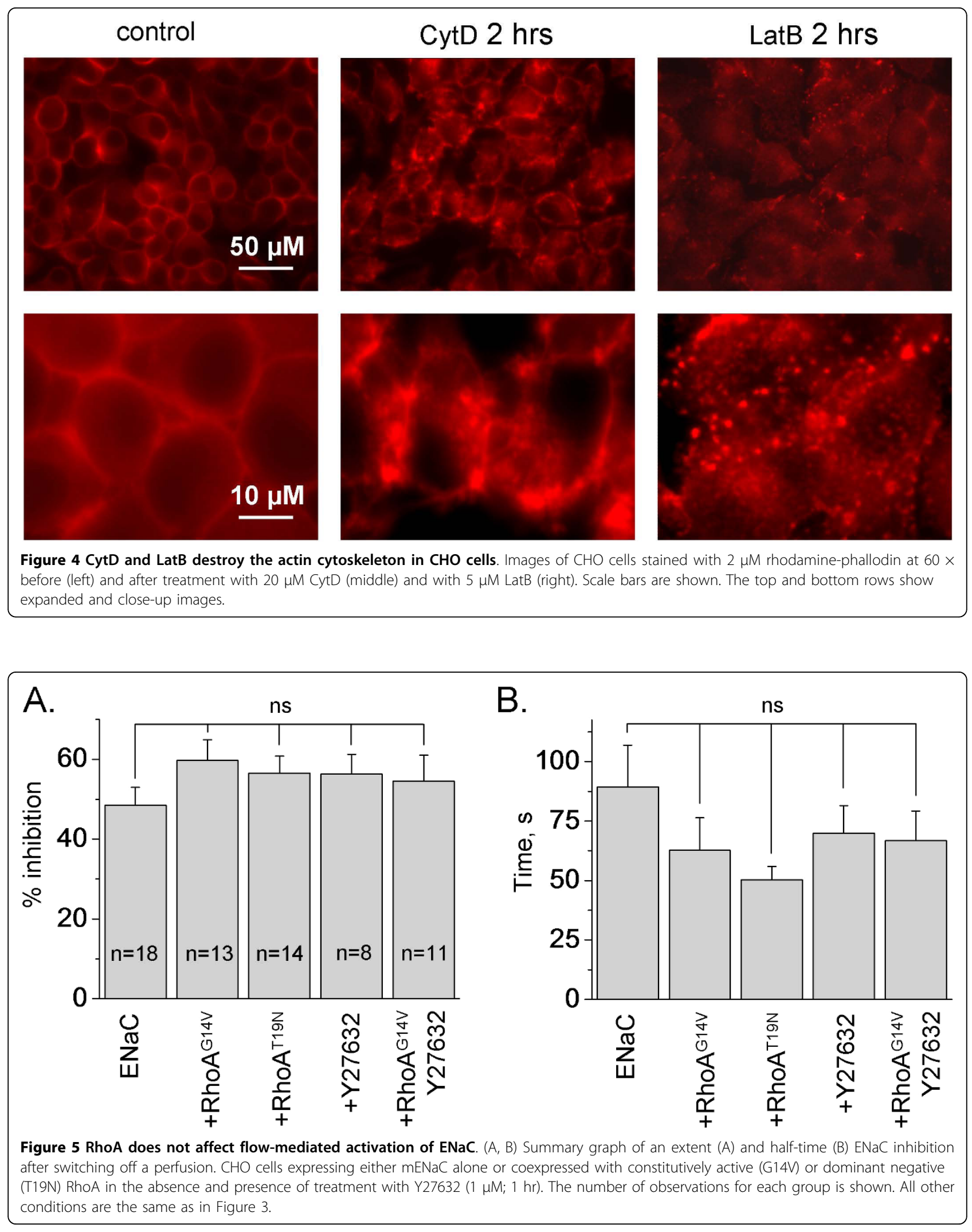
loops localized on every $\mathrm{ENaC}$ subunit can be involved into modulation of the channel's activity [30]. Furthermore it was shown that $\mathrm{ENaCs}$ with deletions of the $\mathrm{COOH}$-terminal domains of the three subunits are still activated by laminar shear stress when expressed in $X$. laevis oocytes [7]. Carattino et al. have proposed that spatial and temporal variations of flow rate in renal tubules produce a deformation of a mechanical sensor that is transduced to the channel gate. Work performed as a result of shear distortion of mechanosensitive structures facilitate conformational changes that eventually gate the channel [34]. Similar to other ion channels, $\mathrm{ENaC}$ activity is regulated, in part, by the actin cytoskeleton. Besides, the cytoskeleton is an established target for small G proteins signaling, and particularly RhoA. In current study we attempted to address the role of the actin cytoskeleton and small GTPases in the mechanical activation of $\mathrm{ENaC}$. However, despite mostly negative findings were established, these results provide new important insights into the control of $\mathrm{ENaC}$.

Sipos et al. recently shown that mechanosensitive connexin 30 hemichannels have an integral role in pressure natriuresis by releasing ATP into the tubular fluid, which inhibits salt and water reabsorption [35]. Apical release of ATP can activate $\mathrm{P}_{2} \mathrm{Y}_{2}$ receptors in the ASDN and inhibit ENaC activity [36,37]. Thus ATP might also be involved in flow-stimulated regulation of ENaC. However this hypothesis requires further investigation.

Achard et al. have shown that pretreatment with colchicine $(0.5 \mathrm{mM}, 30 \mathrm{~min})$ prevented stretch-induced activation of amiloride-sensitive sodium channels in human B lymphocytes [13]. However, Morimoto et al. defined that flow activation of $\mathrm{ENaC}$ is not dependent on intact microtubules [31]. An increase in luminal flow rate in colchicine-treated $(10 \mu \mathrm{M} ; 1 \mathrm{hr})$ tubules was associated with an increase in net $\mathrm{Na}^{+}$absorption and was not different from control CCDs. Awayda and Subramanyam have pretreated $X$. laevis oocytes with Cytochalasin B for 2-5 hrs. rENaC expressed in X. laevis oocytes remained insensitive to mechanical perturbations after disruption of the actin cytoskeleton. However, the authors did not observe mechanosensitivity of the channel even at basal conditions [5].

The rationale for these studies comes from our previously published data showing that several small G proteins, including RhoA and Rac1 alter ENaC activity [21-23,38]. These small G proteins are key signal transduction molecules, not only mediating ligand-induced changes to the actin cytoskeleton, but also implicated in numerous cellular processes including vesicle trafficking. Moreover, recent studies reveal that the cytoskeleton is involved in regulation of $\mathrm{ENaC}$ and is necessary for small G protein mediated increase of ENaC activity [20]. $\mathrm{Yu}$ et al. also observed that in response to a dynamic mechanical environment, increased apical membrane tension, but not pressure, stimulated apical membrane exocytosis and ion transport in bladder umbrella cells. The exocytic response was independent of temperature but required the cytoskeleton and the activity of a nonselective cation channel and the epithelial sodium channel [39]. Consequently, we focused on the flowmediated regulation of $\mathrm{ENaC}$ by the actin cytoskeleton and small GTPase RhoA. Our results suggest that flow activates $\mathrm{ENaC}$ overexpressed in $\mathrm{CHO}$ cells and, furthermore, that this effect is not mediated by the actin cytoskeleton and RhoA/Rho-kinase signaling pathway. Thus, an exact mechanism of ENaC's activation by mechanical forces requires further investigation

\section{Materials and methods cDNA constructs and cell culture}

All chemicals and materials were purchased from either Fisher Scientific or Sigma unless noted otherwise. CHO cells were maintained with standard culture conditions and transfected using Polyfect reagent (Qiagen, Valencia, CA) as described previously [40]. For expression of mouse $\mathrm{ENaC}$ in $\mathrm{CHO}$ cells, subunit cDNA transfection ratios of 1: 1 : 1 were used ( $0.3 \mu \mathrm{g}$ of each cDNA per $35 \mathrm{~mm}$ dish). To define successfully transfected cells $0.5 \mu \mathrm{g}$ of green fluorescent protein cDNA (eGFP) was also added to cDNA mix. The expression vectors encoding constitutively active (G14V) or dominant negative (T19N) RhoA were from the UMR cDNA Resource Center http://www.cdna. org. The mammalian expression vectors encoding $\alpha-, \beta$ and $\gamma$-mouse $\mathrm{ENaC}$ have been described previously [41].

\section{Electrophysiology}

Whole-cell macroscopic current recordings of $\mathrm{mENaC}$ expressed in $\mathrm{CHO}$ cells were made under voltage-clamp conditions using standard methods. In brief, current through $\mathrm{ENaC}$ was the inward, amiloride-sensitive $\mathrm{Na}^{+}$current with a bath solution of (in $\mathrm{mM}$ ) $160 \mathrm{NaCl}$, $1 \mathrm{CaCl}_{2}, 2 \mathrm{MgCl}_{2}$ and 10 HEPES (pH 7.4) and a pipette solution of (in mM) $120 \mathrm{CsCl}, 5 \mathrm{NaCl}, 2 \mathrm{MgCl}_{2}$, 5 EGTA, 10 HEPES, 2.0 ATP and 0.1 GTP (pH 7.4). Current recordings were acquired with an Axopatch 200B (Mol. Devices, Sunnyvale, CA) patch clamp amplifier interfaced via a Digidata 1440A (Mol. Devices) to a PC running the pClamp 10.2 suite of software (Mol. Devices). Cells were clamped to a $40 \mathrm{mV}$ holding potential with voltage ramps $(300 \mathrm{~ms})$ from $60 \mathrm{mV}$ down to $-100 \mathrm{mV}$ used to elicit current. Flow stimulation was applied by switching ValveBank ${ }^{\circ} 8$ Teflon Perfusion System (AutoMate Scientific, Inc.). ENaC activity is the amiloride-sensitive current density at $-80 \mathrm{mV}$. Wholecell capacitance, on average 8-10 pF, was compensated. Series resistances, on average 2-5 $\mathrm{M} \Omega$, were also compensated. 


\section{Staining with rhodamin-phalloidin}

$\mathrm{CHO}$ cells were seeded on $12 \mathrm{~mm}$ round-shaped coverslips coated with Poly-D-Lysine (BD Bioscience) $24 \mathrm{hrs}$ before experiments and grown to confluence of $70 \%$. Before staining the cells were washed with PBS and fixed with $1.2 \%$ paraformaldehyde (Sigma). Then cells were treated with $0,1 \%$ Tryton X-100 (Sigma) for 5 min, washed with PBS and incubated with $2 \mu \mathrm{M}$ rhodamine-phalloidin (Invitrogen) for 15 min at $37^{\circ} \mathrm{C}$. Stained cells were mounted on glass slides with Vectashield mounting Medium (Vector Laboratories).

\section{Microscopy}

$\mathrm{CHO}$ cells stained with rhodamine-phalloidin were visualized with fluorescence microscope Eclipse E-600 (Nikon) using a $60 \times$ oil objective equipped with a CCD camera (Prinston Instruments). The signal was excited at $546 \mathrm{~nm}$ and emission was collected at $590 \mathrm{~nm}$. Fluorescent images were processed with the Metamorph 7.5 software (Molecular Devices) and open source software ImageJ 1.42q http://rsb.info.nih.gov/ij.

\section{Statistics}

All summarized data are reported as means \pm SEM. Tau for $\mathrm{ENaC}$ inhibition was calculated using a single exponential curve. Data are compared using either the Student's (two-tailed) $t$-test or a one way ANOVA and $\mathrm{P}<0.05$ is considered significant.

\section{Acknowledgements}

Glen Slocum is recognized for excellent technical assistance with microscopy experiments. This research was supported by American Heart Association (SDG 0730111N), American Society of Nephrology Carl W. Gottschalk Research Scholar Grant, and American Physiological Society S\&R Foundation Ryuji Ueno Award (to AS). We thank Rob Menzies for critical reading of the manuscript.

\section{Author details}

${ }^{1}$ Department of Physiology, Medical College of Wisconsin, 8701 Watertown Plank Rd., Milwaukee, WI 53226, USA. ${ }^{2}$ Kidney Disease Center, Medical College of Wisconsin, 8701 Watertown Plank Rd., Milwaukee, WI 53226, USA. ${ }^{3}$ Institute of Cytology, Russian Academy of Sciences, St. Petersburg, 194064, Russian Federation.

\section{Authors' contributions}

AVK and DVI carried out the study, participated in its design and coordination and helped to draft the manuscript. AS conceived and designed the experiments, analyzed the data and wrote the paper. All authors read and approved the final manuscript.

\section{Competing interests}

The authors declare that they have no competing interests.

Received: 20 April 2010 Accepted: 27 July 2010 Published: 27 July 2010

\section{References}

1. Garty H, Palmer LG: Epithelial sodium channels: function, structure, and regulation. Physiol Rev 1997, 77:359-396.
2. Schild L: The epithelial sodium channel: from molecule to disease. Rev Physiol Biochem Pharmacol 2004, 151:93-107.

3. Giebisch G: Renal potassium transport: mechanisms and regulation. Am J Physiol 1998, 274:F817-F833.

4. Palmer LG, Frindt G: Gating of Na channels in the rat cortical collecting tubule: effects of voltage and membrane stretch. J Gen Physiol 1996, 107:35-45.

5. Awayda MS, Subramanyam M: Regulation of the epithelial $\mathrm{Na}+$ channel by membrane tension. J Gen Physiol 1998, 112:97-111.

6. Satlin LM, Sheng S, Woda CB, Kleyman TR: Epithelial Na(+) channels are regulated by flow. Am J Physiol Renal Physiol 2001, 280:F1010-F1018.

7. Carattino MD, Sheng S, Kleyman TR: Epithelial Na+ channels are activated by laminar shear stress. J Biol Chem 2004, 279:4120-4126.

8. Althaus M, Bogdan R, Clauss WG, Fronius M: Mechano-sensitivity of epithelial sodium channels (ENaCs): laminar shear stress increases ion channel open probability. FASEB J 2007, 21:2389-2399.

9. Carattino MD, Liu W, Hill WG, Satlin LM, Kleyman TR: Lack of a role of membrane-protein interactions in flow-dependent activation of $\mathrm{ENaC}$. Am J Physiol Renal Physiol 2007, 293:F316-F324.

10. Niisato N, Taruno A, Marunaka Y: Aldosterone-induced modification of osmoregulated ENaC trafficking. Biochem Biophys Res Commun 2007, 361:162-168.

11. Vachugova DV, Morachevskaia EA: Mechanosensitivity of cationic channels of DEG/ENaC family. Tsitologiia 2009, 51:806-814.

12. Staruschenko A, Negulyaev YA, Morachevskaya EA: Actin cytoskeleton disassembly affects conductive properties of stretch-activated cation channels in leukaemia cells. Biochim Biophys Acta 2005, 1669:53-60.

13. Achard JM, Bubien JK, Benos DJ, Warnock DG: Stretch modulates amiloride sensitivity and cation selectivity of sodium channels in human B lymphocytes. Am J Physiol 1996, 270:C224-C234.

14. Hayakawa K, Tatsumi H, Sokabe M: Actin stress fibers transmit and focus force to activate mechanosensitive channels. J Cell Sci 2008, 121:496-503.

15. Cantiello HF: Role of the actin cytoskeleton on epithelial $\mathrm{Na}+$ channel regulation. Kidney Int 1995, 48:970-984.

16. Mazzochi C, Benos DJ, Smith PR: Interaction of epithelial ion channels with the actin-based cytoskeleton. Am J Physiol Renal Physiol 2006, 291: F1113-F1122.

17. Wang WH, Cassola A, Giebisch G: Involvement of actin cytoskeleton in modulation of apical $\mathrm{K}$ channel activity in rat collecting duct. Am J Physiol Renal Physiol 1994, 267:F592-F598.

18. Wei $Y$, Wang $W H$ : Role of the cytoskeleton in mediating effect of vasopressin and herbimycin A on secretory $\mathrm{K}$ channels in CCD. Am J Physiol Renal Physiol 2002, 282:F680-F686.

19. Wu L, Gao X, Brown RC, Heller S, O'Neil RG: Dual role of the TRPV4 channel as a sensor of flow and osmolality in renal epithelial cells. Am J Physiol Renal Physiol 2007, 293:F1699-F1713.

20. Karpushev AV, llatovskaya DV, Pavlov TS, Negulyaev YA, Staruschenko A Intact cytoskeleton is required for small $\mathrm{g}$ protein dependent activation of the epithelial na channel. PLOS ONE 2010, 5:e8827.

21. Pochynyuk O, Medina J, Gamper N, Genth H, Stockand JD, Staruschenko A: Rapid translocation and insertion of the epithelial $\mathrm{Na}+$ channel in response to RhoA signaling. J Biol Chem 2006, 281:26520-26527.

22. Pochynyuk O, Staruschenko A, Bugaj V, Lagrange L, Stockand JD: Quantifying RhoA Facilitated Trafficking of the Epithelial Na+ Channel toward the Plasma Membrane with Total Internal Reflection Fluorescence-Fluorescence Recovery after Photobleaching. J Biol Chem 2007, 282:14576-14585.

23. Staruschenko A, Nichols A, Medina JL, Camacho P, Zheleznova NN, Stockand JD: Rho small GTPases activate the epithelial $\mathrm{Na}(+)$ channel. J Biol Chem 2004, 279:49989-49994.

24. Staruschenko A, Pochynyuk OM, Tong Q, Stockand JD: Ras couples phosphoinositide 3-OH kinase to the epithelial $\mathrm{Na}+$ channel. Biochim Biophys Acta 2005, 1669:108-115.

25. Cooper JA: Effects of cytochalasin and phalloidin on actin. J Cell Biol 1987 105:1473-1478.

26. Wakatsuki T, Schwab B, Thompson NC, Elson EL: Effects of cytochalasin D and latrunculin B on mechanical properties of cells. J Cell Sci 2001, 114:1025-1036.

27. Drummond HA, Grifoni SC, Jernigan NL: A new trick for an old dogma: $\mathrm{ENaC}$ proteins as mechanotransducers in vascular smooth muscle. Physiology (Bethesda) 2008, 23:23-31. 
28. Ji HL, Fuller CM, Benos DJ: Osmotic pressure regulates alpha beta gamma-rENaC expressed in Xenopus oocytes. Am J Physiol 1998, 275: C1182-C1190

29. Awayda MS, Ismailov II, Berdiev BK, Benos DJ: A cloned renal epithelial Na + channel protein displays stretch activation in planar lipid bilayers. Am J Physiol 1995, 268:C1450-C1459.

30. Fronius M, Clauss WG: Mechano-sensitivity of ENaC: may the (shear) force be with you. Pflugers Arch 2008, 455:775-785.

31. Morimoto T, Liu W, Woda C, Carattino MD, Wei Y, Hughey RP, Apodaca G Satlin LM, Kleyman TR: Mechanism underlying flow stimulation of sodium absorption in the mammalian collecting duct. Am J Physiol Renal Physiol 2006, 291:F663-F669.

32. Bhalla $\mathrm{V}$, Hallows KR: Mechanisms of $\mathrm{ENaC}$ regulation and clinical implications. J Am Soc Nephrol 2008, 19:1845-1854.

33. Satlin LM, Carattino MD, Liu W, Kleyman TR: Regulation of cation transport in the distal nephron by mechanical forces. Am J Physiol Renal Physiol 2006, 291:F923-F931.

34. Carattino MD, Sheng S, Kleyman TR: Mutations in the pore region modify epithelial sodium channel gating by shear stress. J Biol Chem 2005, 280:4393-4401.

35. Sipos A, Vargas SL, Toma I, Hanner F, Willecke K, Peti-Peterdi J: Connexin 30 deficiency impairs renal tubular ATP release and pressure natriuresis. J Am Soc Nephrol 2009, 20:1724-1732.

36. Pochynyuk O, Bugaj V, Rieg T, Insel PA, Mironova E, Vallon V, Stockand JD: Paracrine Regulation of the Epithelial $\mathrm{Na}+$ Channel in the Mammalian Collecting Duct by Purinergic P2Y2 Receptor Tone. J Biol Chem 2008, 283:36599-36607.

37. Pochynyuk O, Rieg T, Bugaj V, Schroth J, Fridman A, Boss GR, Insel PA, Stockand JD, Vallon V: Dietary Na+ inhibits the open probability of the epithelial sodium channel in the kidney by enhancing apical P2Y2receptor tone. FASEB J 2010, 24:2056-2065.

38. Pavlov TS, Chahdi A, llatovskaya DV, Levchenko V, Vandewalle A, Pochynyuk O, Sorokin A, Staruschenko A: Endothelin-1 Inhibits the Epithelial $\mathrm{Na}+$ Channel through \{beta\}Pix/14-3-3/Nedd4-2. J Am Soc Nephrol 2010, 21:833-843.

39. Yu W, Khandelwal P, Apodaca G: Distinct apical and basolateral membrane requirements for stretch-induced membrane traffic at the apical surface of bladder umbrella cells. Mol Biol Cell 2009, 20:282-295.

40. Staruschenko A, Patel P, Tong Q, Medina JL, Stockand JD: Ras activates the epithelial $\mathrm{Na}(+)$ channel through phosphoinositide 3-OH kinase signaling. J Biol Chem 2004, 279:37771-37778.

41. Karpushev AV, Levchenko V, Pavlov TS, Lam VY, Vinnakota KC, Vandewalle A, Wakatsuki T, Staruschenko A: Regulation of ENaC expression at the cell surface by Rab11. Biochem Biophys Res Commun 2008, 377:521-525.

doi:10.1186/1756-0500-3-210

Cite this article as: Karpushev et al:: The actin cytoskeleton and small G protein RhoA are not involved in flow-dependent activation of $\mathrm{ENaC}$. BMC Research Notes 2010 3:210.

\section{Submit your next manuscript to BioMed Central and take full advantage of:}

- Convenient online submission

- Thorough peer review

- No space constraints or color figure charges

- Immediate publication on acceptance

- Inclusion in PubMed, CAS, Scopus and Google Scholar

- Research which is freely available for redistribution

Submit your manuscript at www.biomedcentral com/submit
Biomed Central 